\title{
A HISTORICAL VIEW ON THE DEVELOPMENT OF CZECH ECONOMY FROM 1970
}

\section{Kristýna Vltavská, Jaroslav Sixta*}

\begin{abstract}
:
The paper describes the changes in Czech economy in the period between 1970 and 2010 from the macroeconomic perspective. It is based on the detailed study of sources and uses of gross domestic product with respect to labour inputs. Used data sources come from recently published historical data on GDP combined with the data of official statistics. The paper should provide an analysis of the main determinants of growth based on output and expenditure approach to GDP and employment including the industrial analysis of labour productivity. In this paper labour productivity is estimated as the ratio of gross value added in the constant prices over the input used. As we have the data of total employment in full time equivalent we used them as the only possible labour input for the productivity analysis for the period in question.
\end{abstract}

Keywords: system of balance of national economy, system of national accounts, gross domestic product, gross value added, full time equivalent, labour productivity

JEL Classification: E01, C02, N01, O41

\section{Introduction}

Economic development can be described in several ways and currently the most common approach is based on the System of National Accounts (SNA). Since SNA is a very complex and complicated system it is usually not available for historical data. Therefore, only gross domestic product (GDP) - which is the most important indicator reflecting economic development of a country - is widely used. GDP can be simply interpreted as a sum of final products (goods and services) produced in a country on annual or quarterly basis. This simplified definition means that the production process described by created gross valued added plus net taxes on products equals the final use covering final consumption expenditures, gross capital formation and net exports. It has to correspond to income approach constituted by compensation of employees, operating surplus and net taxes on production. The creation and use of gross domestic product is connected with the definition of residents and economic territory, more detailed definition can be found

* Ing. Kristýna Vltavská, Ph.D., University of Economics, Prague, Faculty of Informatics and Statistics Department of Economic Statistics, Nám. W. Churchilla 4, CZ 13067 Praha 3, +420 224095 451, kristyna.vltavska@vse.cz; Ing. Jaroslav Sixta, Ph.D., University of Economics, Prague, Faculty of Informatics and Statistics, Department of Economic Statistics, Nám. W. Churchilla 4, CZ 13067 Praha 3,+420 224095 451, sixta@vse.cz. Authors are also working at the Czech Statistical Office. This paper is prepared under the support of the Project Historical Time Series of Gross Domestic Product of the Czech Republic of the Czech Science Foundation, Project No. P402/10/1275. 
in ESA 1995. GDP is suitable for studying productivity and less suitable for studying living standard. In any case, every analysis needs comparable time series. One of the most important issues of modern statistics is the incomparability of indicators in time or between countries. The same problem appears in macroeconomic statistics ${ }^{1}$. Nowadays, only some of developed countries can offer time series of (at least) GDP before 1990 and mainly post-communist countries offer data starting after 1995. As society is getting more complicated and more tied by an increasing number of laws, directives, regulation etc., statistics is used for administrative purposes rather than for analyses ${ }^{2}$. Reasonably, the emphasis of statistical offices facing budgetary cuts is put on the most demanded issues requested by the most powerful users (ECB, EUROSTAT) instead of the most important ones (universities and research centres). The situation of macroeconomic statistics in the Czech Republic is slightly better than in other post-communist countries and after the revision of national accounts in 2012; its data starts in 1990. However, when analysing a long term development of the country, data for more than 30 or 40 years are necessary. The increased number of questions relating to the development of the Czech Republic before $1990^{3}$ led us to prepare a consistent set of macroeconomic indicators fully compatible with the official data of the Czech Statistical Office (CZSO) ${ }^{4}$. In the following sections we would like to show main macroeconomic tendencies that can be discovered from the reconstructed time series. We also present a rough international comparison while we fully realize all the difficulties. Section 3 offers general descriptions of main tendencies and a rough international comparison. A detailed look at the production side of the economy (value added and employment) is discussed in Section 4. Section 5 describes Czech economy from the expenditure side while households and investments are also compared with selected western countries.

\section{Methodology}

The data starting before 1990 were prepared by our research team at the Department of Economic Statistics at the University of Economics in Prague in cooperation with the Czech Statistical Office. The development of our methodology was strongly influenced by Arvay (1992) and the methodology described in statistical yearbooks (FSO, 1991). It has to be said honestly that such a large project couldn't be successful without senior experts' consults ${ }^{5}$.

1 Unfortunately this is intensified by frequent changes of SNA standards. Even ESA 1995 is not fully implemented because since 2014 a new standard with substantial changes ESA 2010 should be implemented.

2 As an example we can point out the so-called Maastricht treaty criterions. Government deficit, debt, interest rates, consumer price index.

3 The first GDP estimates for the Czechoslovakia were published by Nachtigal (1991). However, he used the simplified methodology of transformation to estimate the GDP for Czechoslovakia. There were some discussions mainly about the value of external trade, investments, non-market industries etc.

4 The data on historical time series are available for free download at the website of the Department of Economic Statistics, University of Economics in Prague http://kest.vse.cz/english/.

5 The authors would like to thank to Mr. Vítězslav Ondruš and Ms. Daniela Marešová for their valuable consultations. 
It is not the aim of this paper to present detailed methodology which is thoroughly described in (Fischer et al. 2013). The key issue is a full consistency of our estimates with the official data of the Czech Statistical Office starting in 1990. The data allow such consistency and therefore the analysis is possible.

All the data prepared by our team originate from data published during socialism on sources and uses of National Income. The published symmetric input-output tables (SIOTs) for the Czech Socialist Republic (1973, 1987) and for Czechoslovakia $(1973,1987)$ represent key indicators. The SIOTs offered a detailed structure of the economy and introduced a lot of information that was hidden to us before. When using this data, we had to face the following difficulties:

a. The originally used System of Balances of National Economy (SBNE) is not consistent with national accounts. Therefore we had to provide bridge tables for transformation of data from SBNE into SNA. While SBNE was covering ${ }^{6}$ only the so-called productive sphere, SNA covers all economic players and moreover it includes many methodical adjustments and imputations.

b. The Czech Socialist Republic was a part of Czechoslovakia and sometimes it was hard to find enough data for separate states (the Czech and Slovak Republics).

c. The change of regime in 1989 and further quick abandoning of SBNE and implementation of SNA caused data inconsistencies and a break in time series.

d. In 2002, a catastrophic flood completely destroyed the Czech Statistical Office and lots of data were inevitably lost.

Even SBNE offered a detailed description of the economy; the core part called Material Product System (MPS) was used for economic development assessment. The key indicator, national income, differed from the presently used gross national income (GNI). This indicator described the value added given by the production process of selected productive industries (the so called productive sphere) and it was based on the net principle (consumption of fixed capital was subtracted). In the currently used GNI primary transfers like dividends and interest with the rest of the world are taken into account and this is very far from the MPS national income (NIMPS). GNI is precisely defined in ESA 1995 but it can be simply described as GDP plus net primary incomes ${ }^{7}$ with non-residents. Detailed overview of all the adjustments of MPS data can be found in Sixta, Fischer (2013) but it is clear that due to the nature of these adjustments that the nominal value of GDP has to be higher than the national income based on the MPS methodology. As the socialist economy was developing in the late 1970s and 1980s, the share of non covered services was increasing and the difference between GDP and NIMPS was increasing, see Table 1.

6 SBNE covered non-productive sphere as well but in form additional tables and this sphere was excluded from the creation of product (not included in Material Product System).

7 Primary incomes cover mainly dividend, interests and reinvested earnings. 
Table 1

The Difference between GDP and NIMPS

\begin{tabular}{|l|l|l|}
\hline \multicolumn{1}{|c|}{$\begin{array}{c}\text { Mational Income based on Material } \\
\text { Product System }\end{array}$} & \multicolumn{1}{|c|}{$\begin{array}{c}\text { Gross domestic product based } \\
\text { on System of National Accounts }\end{array}$} \\
\hline $\begin{array}{l}\text { activities } \\
\text { mark- } \\
\text { activities }\end{array}$ & $\begin{array}{l}\text { Market activities were covered within } \\
\text { the so-called productive sphere. This } \\
\text { sphere covers industries from agriculture, } \\
\text { mining, manufacturing and services for } \\
\text { material sphere (like cargo transport). }\end{array}$ & $\begin{array}{l}\text { Market activities are covered fully and } \\
\text { these activities are defined by ESA 1995. } \\
\text { Industry of the unit is not important for } \\
\text { the definition of market activity. }\end{array}$ \\
$\begin{array}{l}\text { Balances of national income covered } \\
\text { additional tables for the so called non- } \\
\text { productive sphere. This sphere covered } \\
\text { government units and lots of services } \\
\text { provided for households. }\end{array}$ & $\begin{array}{l}\text { Non-market activities are broadly defined } \\
\text { by ESA 1995. These producers cover } \\
\text { mainly government units and non-profit } \\
\text { institutions. }\end{array}$ \\
\hline $\begin{array}{l}\text { Specific } \\
\text { imputation } \\
\text { given by } \\
\text { the concept }\end{array}$ & $\begin{array}{l}\text { Only selected imputations were carried } \\
\text { out like self supply of households and } \\
\text { individual housing construction were } \\
\text { estimated. }\end{array}$ & $\begin{array}{l}\text { Imputations are performed very often. } \\
\text { They are motivated by the effort to increase } \\
\text { the international comparability of national } \\
\text { accounts figures (self supply, individual } \\
\text { housing construction, imputed rent, non- } \\
\text { market output, financial services etc. }\end{array}$ \\
\hline
\end{tabular}

Source: Authors' elaboration

Our system of adjustments was prepared to be implemented not only in the Czech Republic but also in other countries ${ }^{8}$. All the estimates of sources and uses of gross domestic product were designed to fit ESA 1995. When the revised standard ESA (ESA 2010) is put into practice (2014), the set of adjustments will have to be slightly modified. This is intended to be prepared after the Czech Statistical Office publishes revised series of national accounts. The methodology is prepared as a set of adjustments with a corresponding impact on both the source and the use side of the accounts. It can be rather easily implemented in other post-communist countries, as well.

Our methodology focuses on the estimates at current prices and previous year's prices. The approach to statistical deflation currently used cannot be taken over directly. It has to be slightly adjusted. The main problem represents the lack of detailed data and the fact that researchers have to rely on published data and their deflators. We combined published deflators on the industrial level with deflators for all specified adjustments. Generally it means that the totals are obtained as a sum of all individual components. For example, total gross valued added at previous year's prices (pyp) is obtained as a sum of gross value added (at pyp) in all industries. This is different to the previously used method where all the components were revaluated into fixed prices of a selected base year. ${ }^{9}$ Practically it means that our method ensures higher comparability of annual growth rates because the total output is a weighted average of output of all industries with current weights.

8 Our methodology was approved by the Czech Statistical Office, see http://kest.vse.cz/wp-content/ uploads/2012/07/Metodika_MPS_SNA_final.pdf.

9 Details on the methodology of deflation can be found in Fischer et al. (2012) and Jedličková et al. (2009). 


\section{Overall Results}

The last forty years of Czech development was quite dramatic. At first, the so-called normalisation came and the planned economic reforms were stopped ${ }^{10}$. In the late 1970s and 1980s Czech economy was gradually losing competitiveness. Dramatic events in 1989 were followed by economic transformation; a new economic history has started. It is very hard to describe and compare two different economic systems but at least some basic issues can be confronted. Besides the development over the time, it is very interesting to compare Czech economy with the economy of several Western countries. With respect to at least limited comparability and data availability, we selected Austria, the Netherlands and France. Unfortunately, data for Germany are not available.

\subsection{Main indicators of Czech economy in the Period between 1970 and 1990}

The results cover the account of goods and services (see Table 2) for 1970 onwards. Even the methodology is general; due to the availability of data sources we started in $1970^{11}$. The account of goods and services was prepared in a simplified form both at the current and previous year's prices. This is very useful for an analysis of the expenditure approach to GDP, see Section 5.

Table 2

Account of Goods and Services, 1970-1990, current prices, mil. CZK

\begin{tabular}{|l|r|r|r|r|r|c|}
\hline Indicator & 1970 & 1975 & 1976 & 1980 & 1985 & 1990 \\
\hline Output & 615,128 & 825,819 & 860,199 & $1,024,037$ & $1,262,869$ & $1,465,296$ \\
\hline Net taxes on products & 34,224 & 38,187 & 38,979 & 42,149 & 46,112 & 50,075 \\
\hline Imports (only net exports available) & $x$ & $x$ & $x$ & $x$ & 272,878 \\
\hline Total sources & 649,352 & 864,006 & 899,178 & $1,066,186$ & $1,308,981$ & $1,788,249$ \\
\hline Intermediate consumption & 356,398 & 479,947 & 500,795 & 606,939 & 788,353 & 882,680 \\
\hline Final consumption expenditures & 194,705 & 253,271 & 264,329 & 305,670 & 364,429 & 464,904 \\
\hline Gross capital formation & 74,858 & 108,058 & 109,155 & 122,114 & 118,906 & 152,823 \\
\hline Exports (net exports) & 23,391 & 22,730 & 24,899 & 31,463 & 37,293 & 287,842 \\
\hline Total uses & 649,352 & 864,006 & 899,178 & $1,066,186$ & $1,308,981$ & $1,788,249$ \\
\hline Gross value added & 258,730 & 345,872 & 359,404 & 417,098 & 474,516 & 582,616 \\
\hline Gross domestic product & 292,954 & 384,059 & 398,383 & 459,247 & 520,628 & 632,691 \\
\hline
\end{tabular}

Source: 1970-1989 own estimates, since 1990 CZSO

Note: For the years 1970-1989 only net exports (exports - imports) are available, recorded as uses.

10 For more information see Šik (1990).

11 The Czech Socialist Republic was formed on $1^{\text {st }}$ Jannuary 1969, Czechoslovakia became a federation and the data availability increased. 
Since the compilation of GDP at current prices significantly differed from NIMPS, it was necessary to prepare a consistent approach to estimates of GDP at constant prices. We decided to use previous year's prices and the chain-linking method to ensure consistency with official figures published by the Czech Statistical Office since 1990 onwards. It is clear that gross domestic product is therefore obtained by double deflation of gross value added (GVA) and separately deflated taxes and subsidies on products. The following Figure $1^{12}$ describes the real development of gross domestic product.

\section{Figure 1}

Development of GDP and NIMPS, constant prices, previous year $=100,1971-1990$

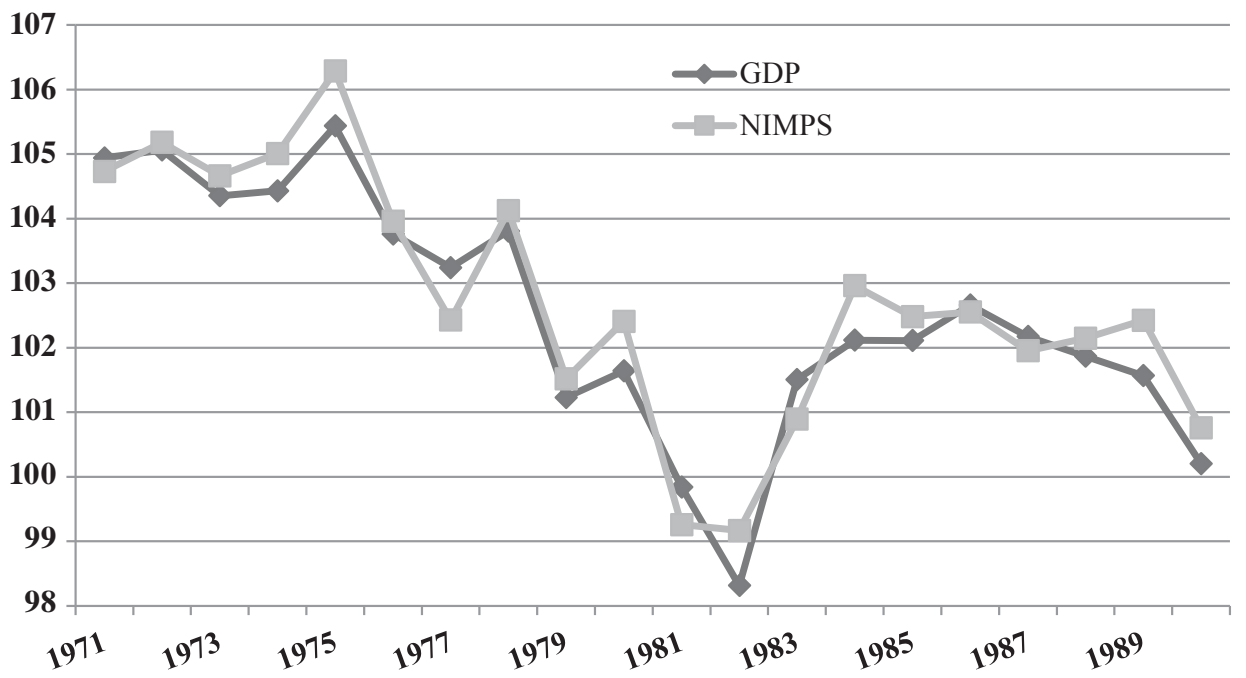

Source: Authors' elaboration

A long time has passed since the social changes in 1989 and therefore we tried not to apply currently valid theories or hypotheses on the period of socialism. We just wanted to change the statistical standard for measuring the economy to assess the development from the perspective of national accounts. It showed us interesting events that played significant roles in our economy thirty or forty years ago. From the point of GDP, Czech economy was decreasing its growth from 1970 s to 1980 s. In 1982 , the economy declined by $1.5 \%$. It was the biggest economic crisis in the whole period of 1971-1990. When the economy recovered, its annual GDP growth oscillated around 2\%. In late 1980s, Czech economy again decreased its growth; in 1989 the economy reached 1.7\%. From the economic point of view, the transformation started after 1991 and in 1990 the unchanged economic system ensured an annual growth of 1\%. On the contrary, in 1991 GDP decreased by $10 \%$.

12 GDP and NIMPS in mil. CZK are shown in Annex 1. 


\subsection{International comparison}

Possibilities of international comparison are very limited due to missing reliable information on parities and exchange rates between socialist and capitalist countries. Even though foreign trade existed and former Czechoslovakia also exported to capitalist countries, these data are not available. A complicated system of exchange rate means that a real market exchange rate cannot be found. These data are available from 1990 onwards, see OECD (2013). In 1990 the average exchange rate of USD/CZK amounted to 21.145 and the purchasing power parity (PPP) for GDP reached 5.52 USD/CZK. Construction of parities cannot be done without detailed information about compared countries and it is usually done by international organisations (OECD, Eurostat). We used parities from both OECD (database for 1990) and Eurostat (database for 2000 and 2010) and recalculated GDP into real terms. Such a rough comparison is based on the published PPP only. Since long time series of macroeconomic data are very rare, we selected at least somehow similar western countries - Austria, the Netherlands and France. Due to very difficult interpretation of international comparison we focused on relative comparisons only and therefore we selected GDP per capita in France as a basis, see Figure 2. The comparison for 1990 is based on USD and the period between the years 2000 and 2010 on PPS (the so called average euro). Such comparison is used only for international matters. The decline of the Czech GDP after 1990 can be clearly identified. For example, in 1990 the ratio of Czech/ Austrian GDP was about 60\%. This ratio declined to 58\% in 2000 and reached $63 \%$ in 2010. A similar ratio is recorded for France. The ratio of Czech/French GDP per capita declined from $68 \%$ to $61 \%$ between the years 1990 and 2000. In 2010, the Czech GDP per capita was about $74 \%$ of the French GDP per capita ${ }^{13}$.

\section{Figure 2}

\section{Comparison of Real Gross Domestic Product per capita with France, \%}

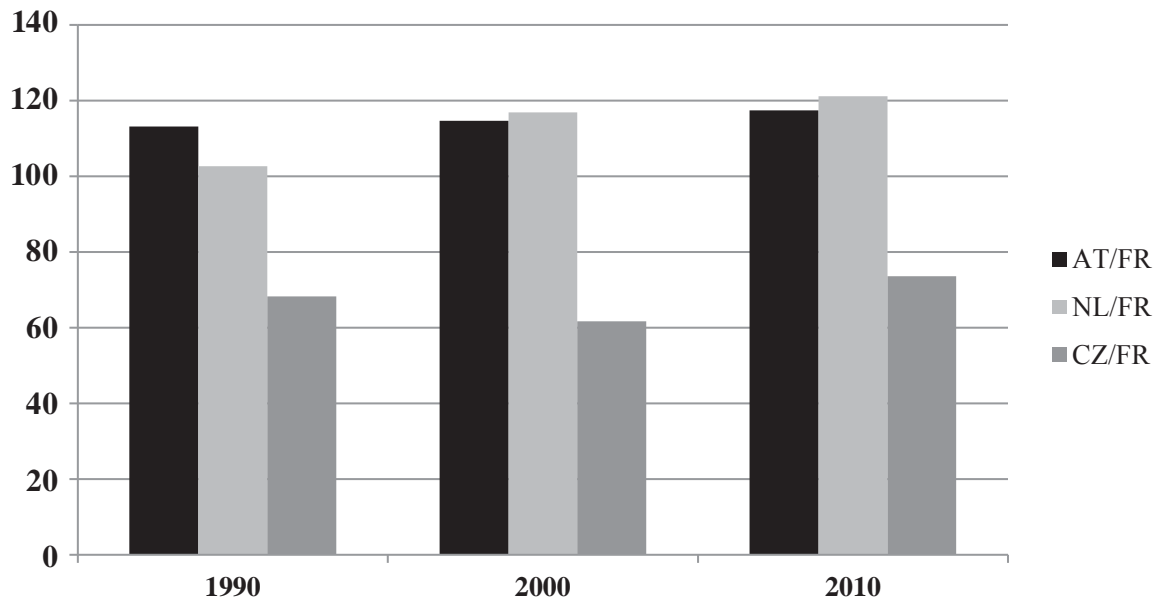

Source: Authors' elaboration for 1990 (USD), 2000 and 2010 Eurostat (PPS)

Notes: AT - Austria, NL - Netherlands, CZ - Czech Republic, FR - France.

13 Different international analysis is performed by Singer (2013). 
Long term development of GDP at constant prices and comparison of the development of France, Austria and the Netherlands is shown in Figure 3. This comparison cannot be used for international purposes but for time comparisons only. Contrary to Figure 2, it is based on volume indices of gross domestic product in national currencies. With respect to the available data source ${ }^{14}$, this comparison has to start in 1976 . We can clearly identify three important milestones in Czech economy; the 1980s when the economy was losing its competitiveness, transformation period between 1990 and 2000 and the current crisis that has started in the $4^{\text {th }}$ quarter of 2008 . It seems that GDP at constant prices of France, Austria and the Netherlands have been increasing almost continuously after 1976 and this represents strong contrast to Czech development. Czech economy has started catching up on developed countries after 2000. It is also clear that Czech economy increased its GDP by $40 \%$ between 1976 and 2005. It is less than the selected western countries but since 2005 the development has reversed. By 2008 Czech economy was rising faster and catching up on the developed countries.

\section{Figure 3}

Development of GDP, constant prices, $2005=100$

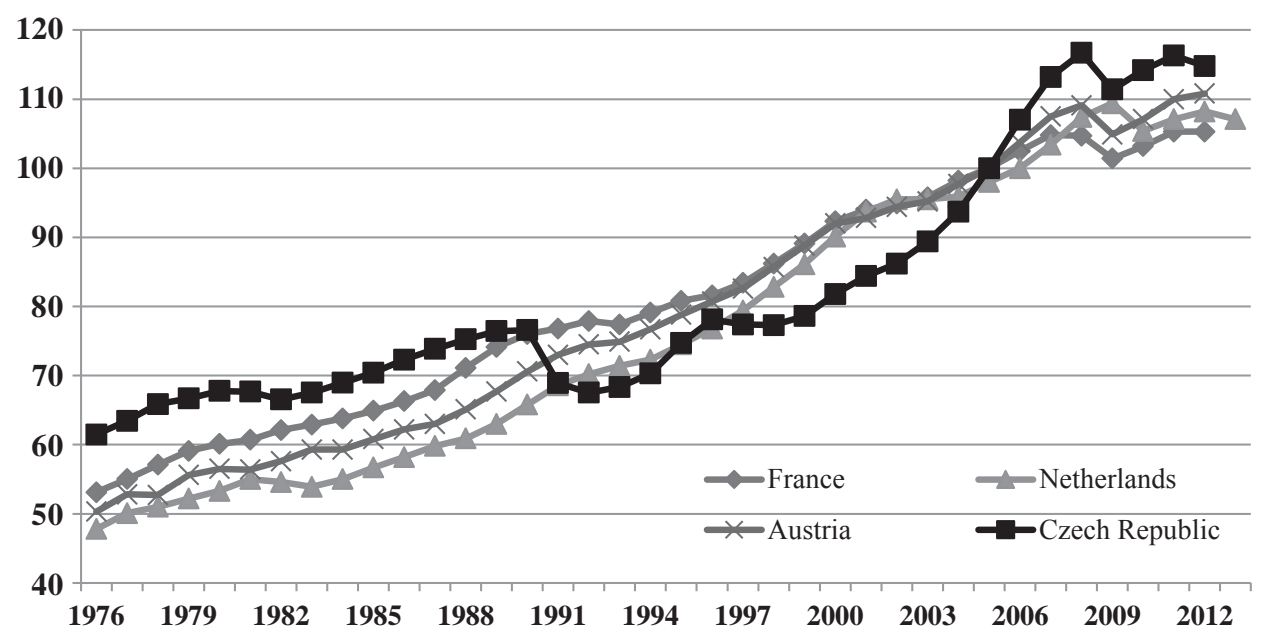

Source: Authors' elaboration, Eurostat

\section{The Development of Czech Economy from the Production Side}

An important part of the development of the country represents the development of gross value added (GVA) and the employment. Historical data bring us the structure of GVA and total employment in full time equivalent. Both of the indicators represent parts of labour productivity measurement. Therefore we estimate the labour productivity of Czech economy from the industrial point of view and compare our results with global labour productivity published in the 1970s.

14 Data were taken over from EUROSTAT database. 


\subsection{Gross Value Added}

Firstly, we focused on the structure of GVA in five-year intervals. The description of the economy is based on the currently used industrial classification NACE rev.2. During the period between the years 1970 and 2010, the structure of Czech economy changed significantly (see Figure 4) ${ }^{15}$.

\section{Figure 4}

Structure of Gross Value Added, current prices, 1970-2010, \%

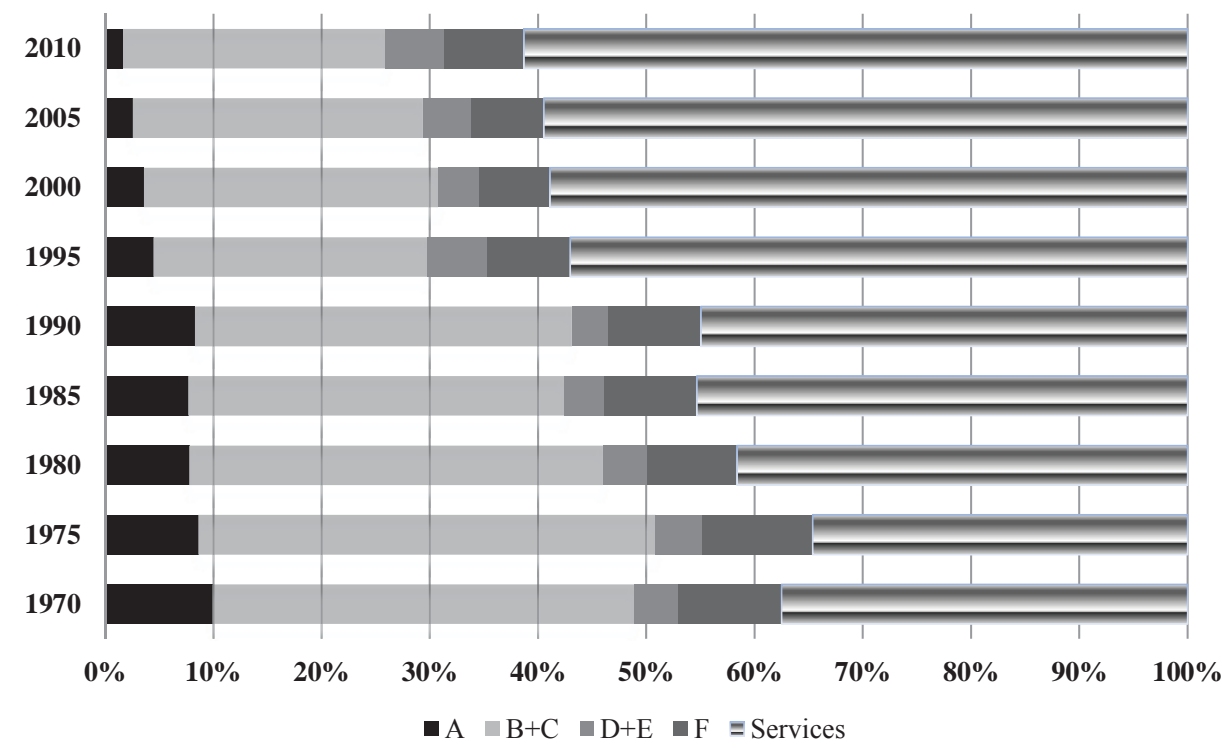

Source: Czech Statistical Office, authors' computation

Note: A - Agriculture, forestry and fishing, B - Mining and quarrying, C - Manufacturing, D - Electricity, gas, steam and air conditioning supply, E - Water supply; sewerage, waste management and remediation activities, F - Construction, Services: G - Wholesale and retail trade; repair of motor vehicles and motorcycles, $\mathrm{H}$ - Transportation and storage, I - Accommodation and food service activities, J - Information and communication, K - Financial and insurance activities, L - Real estate activities, M - Professional, scientific and technical activities, $\mathrm{N}$ - Administrative and support service activities, $\mathrm{O}$ - Public administration and defense; compulsory social security, P - Education, Q - Human health and social work activities, R - Arts, entertainment and recreation, $\mathrm{S}$ - Other service activities, $\mathrm{T}$ - Activities of households as employers and producers for own use.

It is obvious that the changes were fundamental and the current economy is based on totally different foundations than 40 years ago. These issues are solved by a pure statistical approach ${ }^{16}$. The most significant is the decrease of the share of agriculture (A) from $9.9 \%$ in 1970 to $1.66 \%$ in 2010 . Similar development is found in manufacturing and mining; the share of these industries (B and $\mathrm{C}$ ) has decreased by

15 Gross value added of the industries in mil. CZK is shown in Annex 3.

16 It is clear that some changes cannot be fully statistically measured, e.g. the change in quality of personal cars produced in the Czech Republic. 
14 p.p. between the years 1970 and 2010. On the contrary, the share of industries such as energy (D), water and waste (E), construction (F) has changed by approximately from 1 to 2 p.p. Moreover, one can see the increase of the portion of services on GVA of the total economy. While in 1970 GVA of other industries constituted $37.5 \%$ of the total GVA, in 2010 it reached $61.3 \%$.

\subsection{Total employment}

Figure $5^{17}$ describes the structure of employment in the Czech Republic in the period between the years 1970 and 2010. The most interesting element is the significant decrease of industry A - Agriculture, forestry and fishing. While this industry represented $15.21 \%$ of the total employment of the national economy in 1970, in 2010 it was only $3.2 \%$. This development corresponds to the significant decrease of GVA of the industry in question. On the other hand, other industries (financial activities, education, health, etc.) recorded significant increase during the period in question. In 1970 other industries represented $40.2 \%$ of total employment whereas in 1990 it was $41.6 \%$ and in 2010 the segment in question grew to $52.1 \%$ of the total employment. This was connected with over-employment during the socialism when it was necessary to gave employment to the high number of economically active persons even though they had practically nothing to do.

\section{Figure 5}

Structure of Total Employment (full time equivalent), 1970-2010, \%

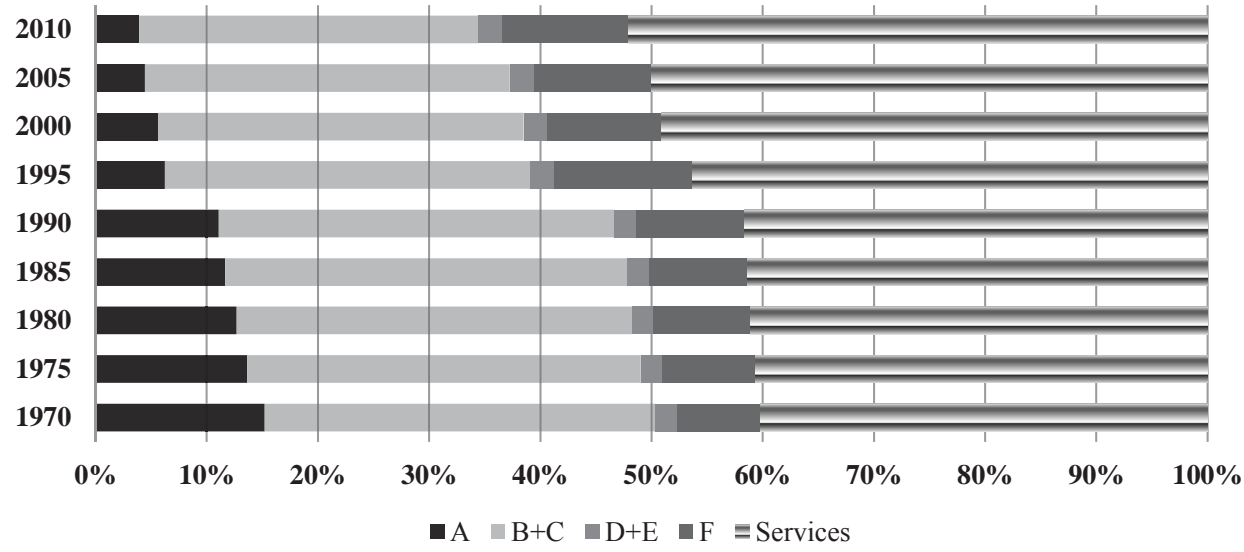

Source: Czech Statistical Office, authors' computation

Note: A - Agriculture, forestry and fishing, B - Mining and quarrying, C - Manufacturing, D - Electricity, gas, steam and air conditioning supply, E - Water supply; sewerage, waste management and remediation activities, F - Construction, Services: G - Wholesale and retail trade; repair of motor vehicles and motorcycles, $\mathrm{H}$ - Transportation and storage, I - Accommodation and food service activities, J - Information and communication, K - Financial and insurance activities, L - Real estate activities, M - Professional, scientific and technical activities, $\mathrm{N}$ - Administrative and support service activities, $\mathrm{O}$ - Public administration and defense; compulsory social security, P - Education, Q - Human health and social work activities, R - Arts, entertainment and recreation, $\mathrm{S}$ - Other service activities, $\mathrm{T}$ - Activities of households as employers and producers for own use.

17 Structure of total employment is shown in Annex 2. 


\subsection{Labour productivity}

Labour productivity represents one of the indicators describing the development of a country. It is estimated as the ratio of volume measure of output and measure of input used. Gross domestic product or gross value added (both at constant prices) could be used as the output variable. Gross domestic product is a suitable indicator for the analysis on the level of the total economy. However, as Fischer and Fischer (2005) pointed out the estimation includes a number of difficulties such as the frequency of estimation, three possible approaches, estimation of shadow economy, etc. On an industrial level gross value added is a more suitable indicator. A possible alternative to the concept of gross aggregates (GDP, GVA) may be offered by using net domestic product and net value added instead. For the estimation of the net aggregates it is necessary to use an estimate of consumption of fixed capital which may not be comparable between countries (due to a different approaches used). To ensure comparability we prefer gross aggregates, namely (with respect to the information mentioned) gross value added.

Labour is the most important input in the production process which is why the selection of the best indicator is an important part of the productivity estimation. We can use one of three different concepts as labour input - total employment in persons, total employment in full time equivalent, number of hours worked and labour services ${ }^{18}$. The OECD Manual (OECD, 2001) and the European standard ESA 1995 (Eurostat, 1996) recommend total hours worked as the most suitable input. This recommendation, however, raises the question of quality of available data sources and quality of estimates of hours worked. Unfortunately the estimation of hours worked in the period between the years 1970 and 1989 was impossible. Therefore we use the total employment in full time equivalent as the input variable. A productivity analysis should include at least capital stocks as well ${ }^{19}$. However, the preparation of capital stocks valued in line with ESA 1995 is very demanding and it was far beyond the targets of our project.

A historical analysis showed that labour productivity in the Czech Republic in comparison to countries reconcilable in size (Austria, the Netherlands) reached barely $55 \%$ of their level. According to the UP (1988) global labour productivity rose by $5.6 \%$ in Czech economy, in the 1970s it grew by $4.0 \%$ and in the $1980 \mathrm{~s}$ the average growth of global labour productivity reached only $2.3 \%$ in the 1960 s.

Using the historical data based on ESA 1995, labour productivity as a combination of gross value added at constant prices of 2005 and employment in full time equivalent lead to very interesting results, see Table 3. During the period between the years 1970 and 2010 the highest labour productivity was achieved in industries D (Electricity, gas, steam and air conditioning supply) and E (Water supply; sewerage, waste management and remediation activities). Industry D contributed a substantial part to the proportion since it represented approximately $80 \%$ of the whole labour productivity of D+E. From the point

18 Labour services take into account not only hours actually worked but also the skills and education of workforce. The estimation of labour services for Czech industries is presented in Sixta, Vltavská, Zbraněk (2011).

19 The estimation of the total factor productivity is widely discussed in Čadil (2007). Čadil et al. (2011) discussed the relationship between the labour input and output from the point of view of the unemployment as well. 
of view of the average annual growth (Table 4) labour productivity of Czech economy was increasing during the period in question. The highest average annual growth was achieved between the years 1970 and 1975 (5.32\%). This was caused by an average annual growth of the gross value added (5.42\%) and a negligible growth in employment $(0.10 \%)$. Between the years 1980 and 1985 the average annual growth of labour productivity of Czech economy attained $0.55 \%$. In this period the gross value added and employment increased by $1.08 \%$ and $0.53 \%$, respectively.

\section{Table 3}

Labour Productivity, constant prices of 2005, CZK

\begin{tabular}{|l|r|r|r|r|r|r|r|r|r|}
\hline & 1970 & 1975 & 1980 & 1985 & 1990 & 1995 & 2000 & 2005 & 2010 \\
\hline $\begin{array}{l}\text { Czech } \\
\text { Republic }\end{array}$ & 245,399 & 318,001 & 357,872 & 367,789 & 388,638 & 428,198 & 474,481 & 570,565 & 643,296 \\
\hline A & 49,932 & 64,057 & 63,581 & 54,476 & 52,526 & 233,209 & 253,540 & 387,213 & 348,594 \\
\hline B+C & 139,739 & 191,047 & 230,284 & 222,469 & 259,750 & 266,566 & 381,808 & 547,641 & 780,453 \\
\hline D+E & 833,092 & $1,083,423$ & $1,268,653$ & $1,201,178$ & $1,253,955$ & $1,268,019$ & $1,226,070$ & $1,383,170$ & $1,256,441$ \\
\hline F & 408,639 & 536,287 & 542,845 & 569,253 & 539,157 & 444,968 & 401,531 & 426,288 & 455,482 \\
\hline G+H & 309,312 & 387,044 & 475,479 & 489,470 & 516,547 & 330,019 & 406,731 & 530,059 & 570,568 \\
\hline Other & 379,509 & 452,804 & 453,937 & 471,231 & 468,811 & 598,808 & 594,789 & 623,304 & 636,174 \\
\hline
\end{tabular}

Source: Czech Statistical Office, authors' computation

From the point of view of individual industries, the highest average annual growth was recorded in the industry A (Agriculture, forestry and fishing) between the years 1990 and 1995 (34.73\%). It was brought about by an increase of gross value added (17.7\%) and a decrease in employment $(-12.6 \%)$. The deepest decrease of labour productivity was registered in industries $\mathrm{G}$ (Wholesale and retail trade; repair of motor vehicles and motorcycles) and $\mathrm{H}$ (Transportation and storage) between the years 1990 and 1995 $(-8.57 \%)$. The reason is a decrease of gross value added and an increase of employment.

\section{Table 4}

\section{Labour Productivity, average annual growth, \%}

\begin{tabular}{|l|c|c|c|c|c|c|c|c|}
\hline & $\mathbf{1 9 7 5 / 1 9 7 0}$ & $\mathbf{1 9 8 0 / 1 9 7 5}$ & $\mathbf{1 9 8 5 / 1 9 8 0}$ & $\mathbf{1 9 9 0 / 1 9 8 5}$ & $\mathbf{1 9 9 5 / 1 9 9 0}$ & $\mathbf{2 0 0 0 / 1 9 9 5}$ & $\mathbf{2 0 0 5 / 2 0 0 0}$ & $\mathbf{2 0 1 0 / 2 0 0 5}$ \\
\hline $\begin{array}{l}\text { Czech } \\
\text { Republic }\end{array}$ & 5.32 & 2.39 & 0.55 & 1.11 & 1.96 & 2.07 & 3.76 & 2.43 \\
\hline A & 5.11 & -0.15 & -3.04 & -0.73 & 34.73 & 1.69 & 8.84 & -2.08 \\
\hline B+C & 6.45 & 3.81 & -0.69 & 3.15 & 0.52 & 7.45 & 7.48 & 7.34 \\
\hline D+E & 5.40 & 3.21 & -1.09 & 0.86 & 0.22 & -0.67 & 2.44 & -1.90 \\
\hline F & 5.59 & 0.24 & 0.95 & -1.08 & -3.77 & -2.03 & 1.20 & 1.33 \\
\hline G+H & 4.59 & 4.20 & 0.58 & 1.08 & -8.57 & 4.27 & 5.44 & 1.48 \\
\hline Other & 3.59 & 0.05 & 0.75 & -0.10 & 5.02 & -0.13 & 0.94 & 0.41 \\
\hline
\end{tabular}

Source: Czech Statistical Office, authors' computation 


\section{Expenditure Approach to GDP}

The development of Czech economy differed between the 1970s and 1980s. The differences can be found in the composition of growth (see Figure 6) and in the development of all components of the expenditure method. Between 1971 and 1975, the annual average growth of the economy was about $5 \%$ with strong growth in final consumption expenditures $(4.5 \%)$ and gross capital formation (9\%). The contribution of final consumption expenditures (covering households and government institutions) to the growth was positive (about 3 percentage points). In 1973 and 1974, strong investment activities added 3.5 p.p. and 3.6 p.p., respectively. Since 1976, the growth of Czech economy has been decelerating. The contribution of final consumption expenditures decreased to about 1.4 p.p. The most significant drop affected investments with an average contribution of about only 0.6 p.p. Moreover, in 1978 gross capital formation declined by $2.2 \%$ and therefore this slowed the growth of economy by 0.6 p.p.

Figure 6

Contribution to Real GDP Growth, 1971-1990, \%

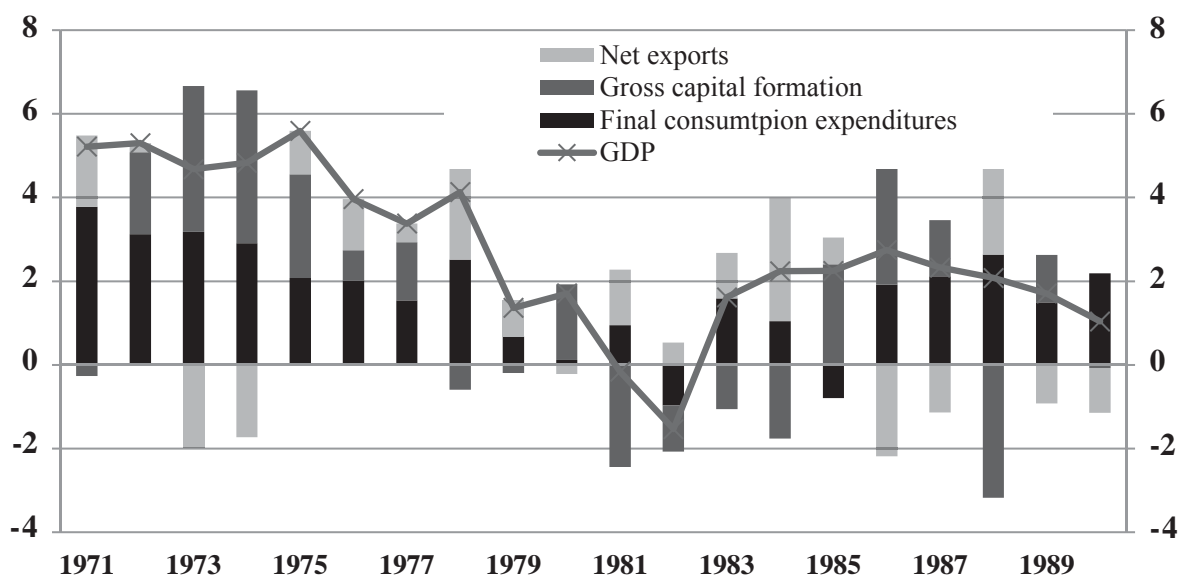

Source: Czech Statistical Office, authors' computation

In 1981, Czech GDP declined by $0.2 \%$ and subsequently the decline deepened to $-1.5 \%$. Gross capital formation decreased in both years with a negative contribution of $2.4 \%$ and $1.1 \%$, respectively. The restored growth after 1982 was driven by the increase of final consumption expenditures while capital formation still had a negative effect. The only exception appeared in 1985 when final consumption declined. Since 1986 the average annual growth of Czech economy was lower than $2 \%$ with a stable contribution of final consumption expenditures of about $2.1 \%$ while the growth of gross capital formation was very low, reaching $0.5 \%$ only. Investment activity fluctuated significantly with an investment peak in 1986 and a drop in 1988. Socialism ended economically in 1990. Since 1991 the development of economy had been very different. Even though investment activity was assessed in the form of its contribution to GDP it has to be taken into account that 
low investments in the late 1970s had to influence the economy in 1980s and undermined subsequently a potential economic growth.

When comparing the investment rate ${ }^{20}$, since the mid 1970 s the rate was continuously decreasing except 1980 (see Table 5). In 1970, the investment rate (hereafter: IR) was about $25.6 \%$ and in $198122.8 \%$. After several years IR fell to its minimum in 1989 (21.1\%). An average IR between 1970 and 1989 reached 24.7\%. This growth is very low in comparison with an average rate in the 1990s (27.9\%). Figure 7 shows the comparison of IR with capitalist countries (France, Austria and the Netherlands). In this relation, IR was higher in the Czech Republic than in France and the Netherlands and it was usually lower that in Austria. Given that the Czech GDP was lower than in all these countries, the results were not very positive (see Table 5 and Figure 7).

\section{Table 5}

Investment Rate and Household Consumption on GDP, Czech Republic, \%

\begin{tabular}{|l|c|c|c|c|c|c|c|c|c|c|}
\hline & 1970 & 1975 & 1980 & 1985 & 1990 & 1995 & 2000 & $\mathbf{2 0 0 5}$ & $\mathbf{2 0 1 0}$ & $\mathbf{2 0 1 2}$ \\
\hline Investment rate (IR) & 25.6 & 28.1 & 26.6 & 22.8 & 24.2 & 32.1 & 29.9 & 26.5 & 24.8 & 23.6 \\
\hline FHCE / GDP & 52.8 & 50.8 & 51.0 & 52.1 & 54.9 & 50.6 & 51.2 & 48.6 & 49.8 & 49.6 \\
\hline
\end{tabular}

Notes: FHCE - Final household consumption expenditures

Figure 7

Investment rate, 1976-2012, \%

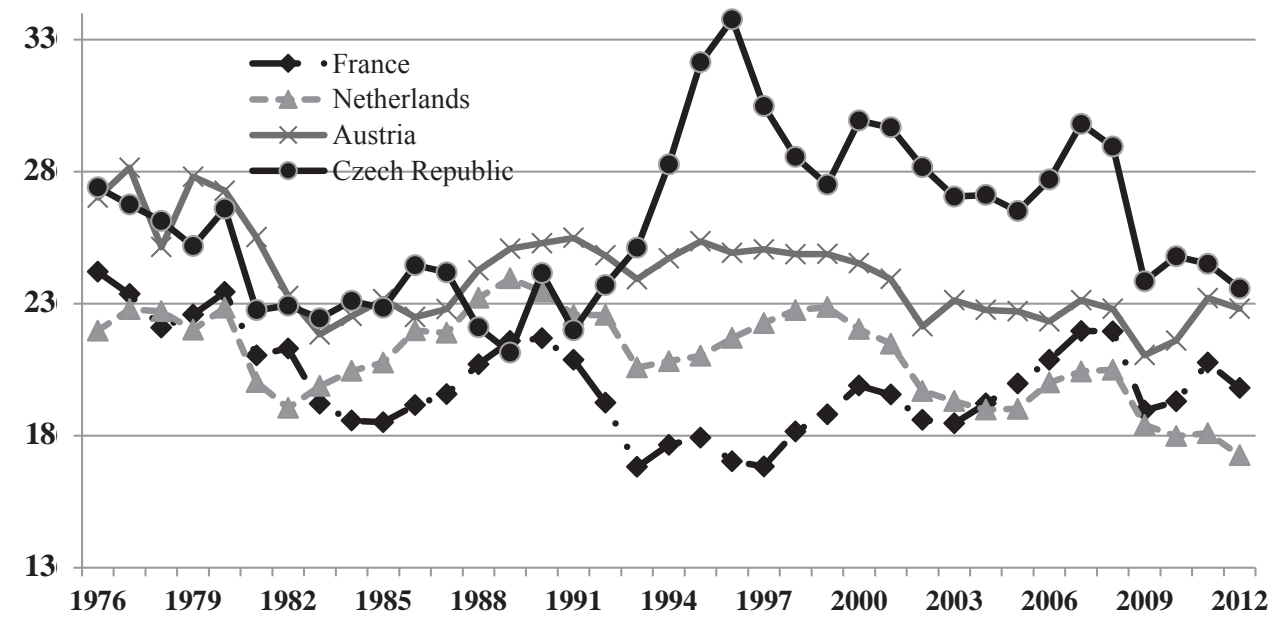

Source: Czech Statistical Office, authors' computation

Contrary to investment, the share of consumption of Czech households was not very different from Western countries (see Figure 8). Czech households consumed about a half

20 We define the investment rate as the share of gross capital formation on GDP. 
of GDP in 1976 and this share rose to nearly 55\% in 1990. That was an opposite trend in comparison with France, the Netherlands and Austria. While investment rate was rising in the 1980s in the Netherlands and the share of consumption was slightly decreasing. It very often stated that the worsening competitiveness of Czech economy was indicated in decline of the rate of investment and substitution of investment by household consumption. Very low investment rate in the 1980s was followed after 1991 with a peak of nearly $34 \%$ in 1996. It seems that Czech economy in the 1980s was rather exhausted and severely underinvested.

\section{Figure 8}

Share of Household Consumption on GDP, 1976-2012, \%

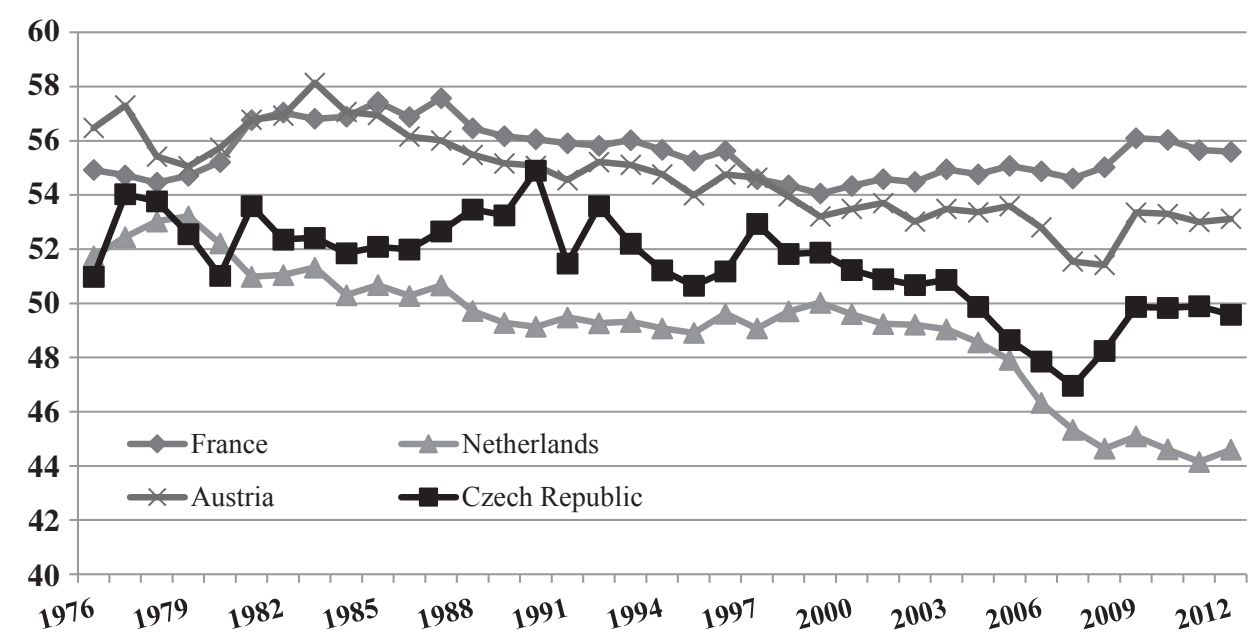

Source: Authors' elaboration, Eurostat

\section{Conclusion}

Availability of long time series of GDP and related macroeconomic indicators is necessary for justified evaluations of development of a country. National accounts compiled by the Czech Statistical Office have been available from 1990 onwards since June 2012. Even though this exceeded Eurostat requirements it was still not sufficient for all users. Within our project we compiled the account of goods and services from 1970 fully compatible with official data. Therefore the key indicator, gross domestic product, is available from 1970 to nowadays. This is an exception between post-communist countries. We focused on the most interesting tendencies of Czech development from the production and expenditure side. We also provided a rough comparison with Western countries. Since the methodology was deeply described in Fischer et al. (2013) we presented only the key methodological issues related to the project.

Overall development of the Czech Republic is described by gross domestic product and its components only. For detailed study about Czech economic development, more indicators would have to be used. The key is the identification of macroeconomic development in the 1970s and 1980s. The gradual loss of competitiveness and oil crisis 
that affected socialist countries later then western capitalist countries resulted in a big decrease of GDP in 1982. Since then Czech economy never fully recovered and after 1991 a new economic system was established. This was connected with a deep decrease of GDP and it took about 5 years to reach the level of 1990. The sharp increase of Czech economy that started after 2000, was stopped in the last quarter of 2008. Since then, Czech economy has been more or less struggling with economic problems.

We also analysed the development of gross value added and total employment in full time equivalent from the industrial point of view. In the 1970s the share of industry A (Agriculture, forestry and fishing) represented 9.9\% of the Czech GVA. In 2010 the share of the industry in question in the total GVA was only $1.66 \%$. This significant decrease was caused by the redirection of Czech economy from the primary to the secondary/ tertiary sectors. The same tendency was recorded in the share of industry A on the total employment $-15.21 \%$ in 1970 and $3.2 \%$ in the year 2010 . The most significant increase of the industrial share of GVA was achieved in other industries (the sum from industry I to industry T), namely 22 p.p. in the period between the years 1970 and 2010. The increase in total employment constitutes 14 p.p. in the period in question. These two indicators are closely related to labour productivity. We computed labour productivity in CZK and as the average annual growth as well. The highest average annual growth was registered in industry A in the period between the years 1990 and 1995 (34.73\%). This increase was caused by the growth of GVA and the drop of total employment. The highest decrease of labour productivity estimated as the average annual growth was recorded in the industry $\mathrm{G}$ (Wholesale and retail trade) and $\mathrm{H}$ (Transportation and storage) and reached $-8.57 \%$ in the period between 1990 and 1995. It was caused by the decrease of GVA and increase of total employment.

When comparing the development of final consumption expenditures and investment, it seems that after 1980 final consumption was very high in comparison with investments. In other words, the investments were low and this undermined another potential development in the 1980s. The created product was used for consumption instead of investment.

Even though the description of Czech economy in the period of socialism has to be very rough and simplified it should provide at least some results. The key is the comparison of the production (measured by GDP) and productivity in time. Structural changes are described on a much aggregated level but this may be used as basis for further analyses. Besides, the development of household consumption is used for comparison of usage of resources (GDP). We wanted to illustrate how these indicators can be used for other more detailed analyses. That is why we prepared and solved the project on the reconstruction of Czech gross domestic product. Our results are available free of charge to anyone on website of the Department of Economic Statistics (kest.vse.cz). 


\section{ANNEX}

Annex 1 NIMPS and GDP, Czech Republic, current process, mil. CSK

\begin{tabular}{|c|c|c|}
\hline Year & NIMPS & GDP \\
\hline 1970 & 221,372 & 292,954 \\
\hline 1971 & 231,590 & 308,959 \\
\hline 1972 & 243,424 & 325,943 \\
\hline 1973 & 256,428 & 344,392 \\
\hline 1974 & 273,453 & 367,076 \\
\hline 1975 & 284,470 & 384,059 \\
\hline 1976 & 292,540 & 398,383 \\
\hline 1977 & 279,774 & 388,891 \\
\hline 1978 & 295,992 & 410,958 \\
\hline 1979 & 313,458 & 434,427 \\
\hline
\end{tabular}

\begin{tabular}{|c|c|c|}
\hline Year & NIMPS & GDP \\
\hline $\mathbf{1 9 8 0}$ & 331,304 & 459,247 \\
\hline $\mathbf{1 9 8 1}$ & 312,940 & 445,452 \\
\hline $\mathbf{1 9 8 2}$ & 332,174 & 471,767 \\
\hline $\mathbf{1 9 8 3}$ & 340,514 & 485,293 \\
\hline $\mathbf{1 9 8 4}$ & 351,865 & 506,003 \\
\hline $\mathbf{1 9 8 5}$ & 361,684 & 520,628 \\
\hline $\mathbf{1 9 8 6}$ & 370,281 & 535,637 \\
\hline $\mathbf{1 9 8 7}$ & 374,210 & 547,156 \\
\hline $\mathbf{1 9 8 8}$ & 385,122 & 560,722 \\
\hline $\mathbf{1 9 8 9}$ & 400,972 & 581,246 \\
\hline
\end{tabular}

Annex 2 Structure of total employment (full time equivalent), Czech Republic

\begin{tabular}{|l|r|r|r|r|r|r|r|r|c|}
\hline & 1970 & 1975 & 1980 & \multicolumn{1}{c|}{1985} & \multicolumn{1}{c|}{1990} & 1995 & $\mathbf{2 0 0 0}$ & $\mathbf{2 0 0 5}$ & $\mathbf{2 0 1 0}$ \\
\hline $\begin{array}{l}\text { Czech } \\
\text { Republic }\end{array}$ & $4,812,921$ & $4,836,211$ & $5,012,374$ & $5,147,302$ & $5,342,443$ & $5,097,321$ & $4,858,481$ & $4,921,124$ & $5,033,887$ \\
\hline A & 731,901 & 646,567 & 601,944 & 554,685 & 530,542 & 269,972 & 234,815 & 185,146 & 160,846 \\
\hline B+C & $1,692,382$ & $1,682,374$ & $1,685,885$ & $1,717,712$ & $1,704,067$ & $1,429,366$ & $1,373,461$ & $1,374,367$ & $1,255,490$ \\
\hline D+E & 93,345 & 92,792 & 92,986 & 94,742 & 93,989 & 93,348 & 90,034 & 90,221 & 88,184 \\
\hline F & 360,100 & 398,436 & 413,326 & 417,795 & 467,226 & 540,091 & 428,662 & 444,047 & 467,768 \\
\hline Services & $1,935,193$ & $1,928,550$ & $1,948,505$ & $1,967,522$ & $1,992,770$ & $2,016,042$ & $2,052,285$ & $2,094,212$ & $2,141,349$ \\
\hline
\end{tabular}

Annex 3 Structure of gross value added, Czech Republic, current prices, mil. CZK

\begin{tabular}{|l|r|r|r|r|r|r|r|r|r|}
\hline & 1970 & 1975 & 1980 & 1985 & 1990 & 1995 & $\mathbf{2 0 0 0}$ & $\mathbf{2 0 0 5}$ & $\mathbf{2 0 1 0}$ \\
\hline $\begin{array}{l}\text { Czech } \\
\text { Republic }\end{array}$ & 258,730 & 345,872 & 417,098 & 474,516 & 582,616 & $1,393,380$ & $2,065,001$ & $2,807,821$ & $3,420,298$ \\
\hline A & 25,619 & 29,754 & 32,440 & 36,484 & 48,336 & 62,219 & 74,301 & 71,691 & 56,659 \\
\hline B+C & 100,826 & 146,181 & 159,447 & 164,679 & 202,943 & 353,142 & 560,959 & 752,660 & 829,481 \\
\hline D+E & 10,533 & 14,727 & 17,284 & 17,602 & 19,675 & 76,282 & 77,933 & 124,791 & 185,974 \\
\hline F & 24,755 & 35,490 & 34,394 & 40,708 & 49,690 & 107,128 & 135,607 & 189,292 & 250,786 \\
\hline G+H & 40,270 & 43,332 & 72,796 & 84,570 & 101,048 & 250,058 & 405,659 & 528,136 & 598,898 \\
\hline Services & 96,997 & 119,720 & 173,533 & 215,043 & 261,972 & 794,609 & $1,216,201$ & $1,669,387$ & $2,097,398$ \\
\hline
\end{tabular}




\section{References}

Arvay, J. (1992), "The Material Product System (BNH): A Retrospective." Paper presented at the Twenty-second General Conference of the International Association for Research of Income and Wealth (IARIW), Switzerland.

Czech Statistical Office (CZSO) (1987), Selected Indicators of the Balance of Sources and Uses of Global Product and National Income 1980-1985. Prague: Czech Statistical Office.

Čadil, J. (2007), "Growth Accounting, Total Factor Productivity and Approximation Problem." Prague Economic Papers, Vol. 12, No. 4, pp. 347-357.

Čadil, J., Pavelka, T., Kaňková, E., Vorlíček, J. (2011), “Odhad nákladů nezaměstnanosti z pohledu veřejných rozpočtů." [Unemployment Cost Estimate from Public Budgets Perspective.] Politická ekonomie, Vol. 59, No. 5, pp. 618-637.

EUROSTAT (1996), European System of Accounts (ESA 1995). Luxembourg: Eurostat.

EUROSTAT (2011), European System of Accounts (ESA 2010). Luxembourg: Eurostat.

Federal Statistical Office (FSO) (1990), Statistical Yearbook 1990, Federal Statistical Office of Czechoslovakia. Prague: Federal Statistical Office.

Fischer, J., Fischer, J. (2005), “Měříme správně hrubý domácí produkt?" Statistika, Vol. 42, No. 3, pp. 177-187.

Fischer, J., Sixta, J. (2009), "K propočtu souhrnné produktivity faktorů", [Towards the Estimation of Total Factor Productivity]. Politická ekonomie, Vol. 57, No. 5, pp. 544-554.

Fischer, J., Sixta J., Hronová, S., Hindls, R., Vltavská, K. (2013), “Odhady zdrojů a užití hrubého domácího produktu ČR pro roky 1970-1989 v metodice ESA 1995." [The Estimates of the Czech Gross Domestic Product for the Years 1970-1989 Based on ESA 1995.] Politická ekonomie, Vol. 61, No. 1, pp. 3-23.

Jedličková, E., Konvička, S., Musil, P., Sixta, J. (2009), “Nové metody deflace HDP.” Statistika, Vol. 89, No. 3, pp. 193-206.

Nachtigal, V. (1991), "Retrospektivní propočty makroekonomických agregátů ČSFR za roky 1970-1988." Statistika, Vol. 28, No. 3, pp. 97-115.

OECD (2013), PPPs and Exchange Rates. Online http://stats.oecd.org/

OECD (2001), Measuring Productivity. Paris: Organization for Economic Cooperation and Development.

Singer, M. (2013), "A Comparison of the Rates of Growth of Post-Transformation Economies: What Can(not) be Expected from GDP?" Prague Economic Papers, Vol. 18, No. 1, pp. 3-33.

Sixta, J., Fischer, J. (2013), "Using Input-Output Tables for Estimates of Czech GDP 1970-1989." Economic Systems Research. Vol. 26, No. 2, pp. 177-196.

Sixta, J., Vltavská, K., Zbranek, J. (2011), “Souhrnná produktivita faktorů založená na službách práce a kapitálu." [Total Factor Productivity Measurement Based on Labour and Capital Service.] Politická ekonomie, Vol. 59, No. 5, pp. 599-617.

ŠIK, O. (1990), Jarní probuzení-iluze a skutečnost. Prague: Mladá fronta.

ÚSTAV PROGNÓZOVÁNÍ ČSR (1988), Souhrnná prognóza ekonomického a sociálního rozvoje ČSR. Prague. 